\title{
Being and the dialectics of irony: A reading of some of Milan Kundera's novels ${ }^{1}$
}

Herselman Hattingh

Department of Philosophy

Rand Afrikaans University

JOHANNESBURG

\begin{abstract}
Being and the dialectics of irony: A reading of some of Milan Kundera's novels

In this essay Milan Kundera is read as an artist who has something to say on the subject of being. He is also read as an ironist in the postmodern vein, an ironist whose writing shatters reader and author alike. The essay thus runs two processes simultaneously: Firstly it is a quasi-theoretical attempt at establishing Kundera's idea of being. Secondly it will be an attempt at showing how Kundera's ironising function is manifested in the novels themselves.
\end{abstract}

\section{Exordium: Art and irony}

In this essay I shall read Milan Kundera as an artist who has something to say on the subject of being. Here, in the exordium it is perhaps important to say something not about what Kundera says, but rather about how he says it. By discussing the how of Kundera's writing, we are trying to establish the outline of a meta-theoretical account of how the subject of being is presented.

Kundera presents the subject of being through the medium of irony. Irony, as the term is used here, is not merely a trope, but a veritable mode of understanding. But to see how irony can become a mode of understanding,

This essay is a revised version of a M.A. paper written under the supervision of Prof. Hennie Lötter and Prof. Johan Snyman, RAU. 
we must link it to its historico-philosophical heritage.

More than anyone else, it was Friedrich von Schlegel who introduced the term irony into modern literary theory. It is the aim of the artist to present the reader with the world in its essence. ${ }^{2}$ But, for Schlegel, as for Fichte, the ego is the absolute principle of all knowing and understanding. This means that everything that is understood or conceived to be true, is done so, purely by the instrumentality of the ego. Every idea that is thus created by the ego, can be destroyed by the ego and so cannot have any value in itself. What the artist does, is to build up an artistic illusion, only to annihilate it by revealing the artist to be the arbitrary creator of this illusion. The ego can only acknowledge its own subjectivity; the rest is mere illusion, created by the ego. The ego's response towards the reality it has created can only be one of irony.

But this ironic stance is hard to bear and there always remains the need for objective reality. The artist can only have an ambivalent attitude towards the world and attempt to curb the struggle between the absolute and the relative by employing irony. So, there exists, in the artist, simultaneously the need to give a complete account of reality and a consciousness of its impossibility. With this dichotomy in mind, the artist cannot submerge herself in her work. To constantly take account of the flux between absolute and relative, she has to stand detached from her work, hovering above it in a state of detachment and superiority.

What remains, is only the artist's subjectivity which can attach itself to nothing (because of the ironic stance) and thus becomes empty. Yet, as we have seen, it constantly yearns to be filled with some absolute, but this proves to be impossible as everything that is not ego or subjectivity itself, is recognised, organised and thus created or annihilated by the ego.

Nevertheless Schlegel still envisages a world that can be comprehended. Of course this comprehension cannot take place in a direct fashion, but rather in the flux between truth and its destruction by irony. The world is constituted in this to and fro movement of creation and ironic unmasking.

See Szondi's article on Schlegel's romantic irony (Szondi, 1985). 
In twentieth century literature we see a definite consciousness of the annihilating function of irony. Modernity's search for the essence of being is characterised by a recognition of incoherence. The world we experience is depicted in terms of its unintelligibility. There exists an ironic distance between the artist's attempts at making reality coherent and her knowledge that the world does not present itself in a coherent fashion. Thus modernity simultaneously attempts to be true to this incoherence and to transcend it. In this way we see that in Joyce and Woolf, the dichotomy between coherence and incoherence is not so much resolved as thrown into aesthetic shape. The paradoxes are not solved, but unified by form, which transcends it.

But in modernist writing we still perceive the belief in a deeper level of truth, a universal meaning which is not completely dependent upon the creative function of the artist, but may be comprehended by the artist. In Woolf we see a manifestation of this possibility of truth in her idea of moments of vision and in Joyce the possibility is lodged in the idea of an epiphany. What remains through the existence of the aestheticising function of the artist and these moments of 'lucidity', is a very strong sense of the artist as creator of meaning. Here, in modernism, there are still strong traces of the ego and Schlegel's subjectivity standing back in a privileged position - adjudicating, if not creating appearances.

What still conspicuously remains in modernist writing is the belief in the unironised subject which is situated in the artist. The artist, through the process of aestheticization and certain moments of lucidity, still possesses the power to transform what seems to be inherently fragmented, into a comprehensible whole. Much of the detached aloofness of Schlegel's artist still remains intact. There is the nostalgia for unity and a basic understanding that this unity is lost and yet there is a persistent adherence to the belief that the artist, through the process of creation, can transcend it and supply what is needed for our understanding of the world and of being.

I am arguing that irony and ironising in Schlegel, as well as in modernism, stops short of the creative subject. Irony, as we have described it up to now, has very little in common with the constructive irony one associates with the Socratic method. There irony functions as a basis for new insights. Irony, as Socrates employs it, always assumes that whatever is 
demolished by it, will presently be replaced with a new understanding. The irony of modernism is much more destructive and the understanding we gain is based on something as volatile as the insights of the creative subject. And yet, we still have, at least, the creative subject, who has become much more important, viewed in the light of the diminishing value of all other certainties.

In postmodern literature this last vestige of truth and order seems to vanish. Irony is taken all the way and is now also allowed to erase the traces of the artist. Kundera creates different possibilities of being. The reader is never confronted by what she is, but rather by what she could be. The possibilities are infinite and the reader receives answers to the problem, only to see these answers being ironised and annihilated. The laughter we, however, hear when all has been ironised, is no longer the laughter of the creating subject, but the laughter of true and uncompromising irony which shatters reader and author alike.

It is with this view of postmodern irony that we shall read the novels of Milan Kundera in order to see what he says about being. We shall thus run two processes simultaneously in this reading. The first is a quasitheoretical attempt to establish Kundera's idea of being. The other will be an attempt to show how the meta-theoretical content we have just been describing is manifested in the novels themselves.

\section{Note to the reader}

Whenever we ask questions about being and the self, we, as philosophers, immediately turn to other philosophers in order to find answers. Perhaps we assume that we are most likely to learn something from philosophers because their work is firstly well structured and argued. Secondly we know that they set out with the idea of providing answers to questions.

What I aim to do in this essay, is to examine the work of a novelist, namely Milan Kundera. I initially set out by posing only one question. The question was formulated in philosophical terms and it read as follows: 'What is being?' I, however, did not find an answer to this question in the novels that I read. Instead I ended up with an answer to another question which reads as follows: 'How is being?' or more conventionally, 'What is being like?' 
Not being a philosopher, Kundera never sets out to answer the first question and therefore we should not be surprised at the outcome of our study. He does answer the second question and he does so in the mode of description. He does not argue for or against a certain conception of what being is, but rather provides us with a description of what being is like. In every novel he answers the same question by a redescription of being. Kundera makes his view of being seem plausible by describing human action.

In 'showing' us being by using the mode of description, Kundera is doing nothing that alienates his writing from other novels. All novels (the most didactic of them excluded) set out to show a world with which the reader is confronted and invited to join or oppose. In the dialectic between the reader's world and the novel's world, a new world comes into existence a world in which the reader suddenly finds himself revealed.

But is this not also true of philosophy? What does Heidegger do in Being and Time (1964)? He does not so much create definitions and make distinctions; what he rather does, is to develop a vocabulary (a new terminology). He does not argue for what is there and what should already be obvious. He does attempt to bring to light that which we have not suspected as being present. One could even go further by saying that the world he shows us, is one that is created in the image of a new language, a language that uncovers a world that had hitherto not existed.

Perhaps the question Kundera sets out to answer can yet again be reformulated as 'What is called being?' In answering this question, Kundera adopts elements of both philosophical and literary rhetoric (or rather, what is traditionally understood as philosophical and literary rhetoric). In the title The Unbearable Lightness of Being (1984), several questions are implicitly formulated:

* What is the nature of being?

* What metaphor should we use to describe being?

* If we use the metaphor of lightness, can being be said to exhibit the qualities of lightness?

* If this can be accomplished, is being, then, bearable or not?

These questions, slightly differently stated perhaps, are certainly not alien to philosophy, but what they do imply, philosophically speaking, is some 
kind of argument that will lead us closer to the proposed solutions. In answering, or more precisely, in providing the ground on which an answer can be formulated, Kundera does something akin to what we have seen Heidegger doing. Heidegger, it is true, never tells us stories which contain characters, but he does use metaphors and images to create meaning. Kundera's characters are born out of metaphors and exist in terms of metaphors. In his stories, he juxtaposes images, metaphors and similes in such a way that they reveal certain aspects of being to the reader. More often than not this juxtapositioning leads his insights and revelations to assume the character of irony. In establishing this ironic character in all his novels, Kundera creates a space in which the revelations the reader has about being, are constantly thrown back onto themselves, constantly challenging one another. In this way, he creates descriptions (novels) of being in which no description is absolutely valid, no image final, and in which no irony is left unironised.

I do not want to impose a homogenised, unified description of being on Kundera's works. Such a description would cripple the playfulness of his novels. But it is also true that, from what we have just said, it becomes possible to say that there exists some kind of substratum which remains evident in all Kundera's descriptions of being; a kind of meta-description of being that might finally be described in terms of the word irony. This is perhaps Kundera's revelation: The world of being is governed by irony and where irony governs, we would do well not to look for any continuity of being. Thus having formulated Kundera's revelation in the negative, it becomes apparent that it is a revelation of denial.

Having already said this much about Kundera's view of being, it is important that our reading of his works should not be monopolised by this idea. If we were to impose this idea on the texts we are about to read, it would make our reading useless and above all, boring. We should, however, not be completely surprised if this meta-description of being should surface at the other end of our reading.

In attempting to understand what it is that Kundera reveals, I shall use a very specific method. For each novel I have chosen a governing metaphor, or several of these. Some metaphors are directly derived from the title and others are taken from the darker recesses of the text. The logic behind this 
method of reading is obvious: If Kundera reveals being in terms of metaphors and images, it is precisely those metaphors and images that should attract our attention. The question is not: 'Why does one study Kundera's metaphors?', but rather, 'Why does one study these specific metaphors?' From the outset it should be clear that the choice of metaphors which I have chosen for discussion, are to a great extent arbitrary. Should one be tempted to use different metaphors, the conclusions of the reading may be radically altered. But this situation is not new to those who read and reread texts. One reading always usurps the space of another. For every reading, there is always a reading that is omitted and denied a space. This understanding of reading will in its own way reveal to us the lightness of reading (or interpretation). In this way, my method of interpretation aspires to emulate Kundera's description of being, not only in content, but also in form and method. While my reading dominates the text and excludes other readings, it opens the space for other readings to come into existence elsewhere. Perhaps it is not only life, but also meaning that is always elsewhere. This elsewhere always remains a possibility. Kundera's characters and metaphors are nothing but expressions of different possibilities. We are offered all these possibilities, and in reading, our purpose should be to play with them.

\section{Being and the death of God}

In this section we read The Joke (1982) as a novel which reverberates with the death of God. We read the book as a finger (the author's writing hand) pointing into the distance where we perceive only the absence of an horizon, a world that has been unchained ... and so on.

The essence of The Joke is transgression. Transgression is the overstepping of bounds, the breaking of new ground, or perhaps, as we shall see, a fall into groundlessness. As we trace the moments of transgression in this novel, we find that transgression takes place on many sites and that it is usually governed by laughter. But the laughter that, here, serves as governing principle, has nothing in common with frivolous humour. In The Joke we find the laughter of loss and bitterness. This laughter is activated by irony and cynicism.

So, in concluding these opening remarks, we can summarise: What we find in this novel is nothing but absence (whose principal metaphor is the 
death of God), initially generated by the act of transgression and which is in turn accomplished by laughter which finds its roots in the sombre twins, irony and cynicism.

But why is this laughter so savage? The fall into the void is born of the dichotomy between two worlds. In the one world Ludvic understands the mechanisms of irony. He is able to laugh. In the other, we find totalitarian humourlessness. The serious face of totalitarian politics is equated with the grave mask of religion. " $[\mathrm{N}] \mathrm{o}$ great movement designed to change the world can bear to be laughed at or belittled. Mockery is a rust that corrodes all it touches" (Kundera, 1982:203). The void which is laughter opens there where the recognition of absence, transience, and contingency meet the wall of certainty.

This dichotomy also forms the political dimension of the book. If we, however, are to understand the book and what it says about being, we are forced to go beyond politics, beyond the critique of totalitarianism. This political dimension is present throughout the novel and yet, its most distinctive voice is heard in the earlier parts of the novel. Let us for the sake of clarity divide the novel into two parts, or rather, two concerns. In the first, Ludvic sends a postcard to his girl friend. This postcard, which reads as follows: "Optimism is the opium of the people! A healthy atmosphere stinks of stupidity! Long live Trotsky!" (Kundera, 1982:26), offends the party's sensibilities. Ludvic's laughter has to face the humourless wall of totalitarianism. His initial laughter, after writing the message, is engendered by his sexual longing for the girl. The postcard is nothing but a retaliation against her sexual passivity and her unwillingness to transgress the boundaries of the sexual. Ludvic's retaliation is political in form, but sexual in nature. Notwithstanding this obvious incongruity, which provokes laughter on the reader's side, Ludvic is sent to work in the mines. His double-edged laughter (which has now been forced to take on both a political and a sexual face), which follows his transgression, leads him into a state of nothingness. He now lives in the absence of freedom, love, and his own personal history. In this way, laughter engenders loss.

But this form of transgression, its resultant absences and its political implications, is only a part of what Kundera has to reveal. For, as we have said at the outset, he will reveal to us the death of God - the most 
profound emptiness.

The second part of the novel deals with Ludvic's retaliation and revenge. His fighting back takes the form of a transgression of social and sexual norms. He intends to sleep with Helena, the wife of his one-time judge and executioner. In cuckolding him, Ludvic will attempt to overcome the emptiness created by the ironic outcome of his joke. He will turn the irony, once directed at him, against his enemy.

We, however, have to ask: What has become of the postcard? It is important to note that, in Ludvic's mind, the postcard is now divested of its humorous element. As it was the sole creator of his fall into absence, it has become serious. It seems to have taken on a constitutive role in Ludvic's life. He can no longer laugh at its contents, for that laughter would dismantle him completely. The postcard, in short, has become heavy. It loses its meaninglessness and becomes a token of Ludvic's individuality. (The token, that which stands for something else is always filled with significance and cannot contend with the annihilation brought about by laughter.) It takes on the meaning of a statement which conquers the dissembling of the self which is the ultimate goal of homogenisation. The postcard makes Ludvic an individual and thus heavy.

Ludvic is in need of something to laugh at, something at which he can direct irony, as it has been directed at him. The enemy's wife becomes that solid object. He is ready to transgress against norms and to reap the rich constitutional laughter of his own ironic creation. But again the joke is on him. Husband and wife have long since stopped caring for each other and readily tolerate infidelity. The proposedly heavy irony turns against Ludvic and in the same motion, becomes light with the sound of laughter. His laughter is, once more, not directed at an object, a system, an enemy, but at himself. Now laughter is again destructive. In the instant that laughter consumes him, Ludvic experiences a moment of weightlessness (Kundera, 1982:210). He becomes a dissolving image, a desolate landscape with no footprints, no heavy traces of presence.

What, precisely did Ludvic have in mind when he slept with Helena? He had wanted to cross the boundary of the present and change the lightness of the past. Revenge takes the form of a looking back that tries to capture 
and alter what has been. But, in crossing this divide, Ludvic finds that he has again become the object of a joke.

He happens to come across members of the new generation of revolutionaries. They now form the party at which his anger is directed. He comes to understand that the postcard (which, as we shall remember, had by this time taken on the heaviness of meaning for Ludvic) has become, for them, a mere joke. What has become for Ludvic the token of his revolt, his very individuality, is now merely smiled at and tolerated. His initial transgression loses its importance at the very same moment when he discovers his impotence to make a heavy indentation on the past. Yet he had suffered defeat and humiliation for it. The laughter directed at him, dilutes his past, makes it watery and insignificant. His past treats him like a stranger (Kundera, 1982:236). He understands the desolation created by this lack of historical solidness when he reflects that:

... most people willingly deceive themselves with a doubly false faith; they believe in eternal memory ... and in rectification ... Both are sham. The truth lies at the opposite end of the scale: everything will be forgotten and nothing will be rectified. All rectification (both vengeance and forgiveness) will be taken over by oblivion. No one will rectify wrongs; all wrongs will be forgotten (Kundera, 1982:245).

And so we take leave of a world in which being becomes a void - there is nothing to refer to, no history, no love, only irony which gives way to the laughter that demolishes.

In this novel we are introduced to what could be called the 'dialectics of irony'. Seriousness is constantly being undermined. When one examines concepts such as being and the self, one is constantly aware of the fact that some measure of seriousness is necessary if one is to go about it constructively at all. Seriousness is the ground for our contemplation of these matters. Kundera starts off by setting up a series of situations in which he creates (in the reader) this seriousness, this groundedness and then he suddenly confronts the reader with a situation which is juxtaposed with what has gone before in such a way that it undermines the seriousness and evokes laughter. But this ironic laughter has a very specific character. It is not the frivolous laughter elicited by a funny situation, but rather the near hysterical laughter evoked by a sense of loss. One comes to see, in the moment of irony, that whatever had been deemed serious, cannot be 
serious. But the laughter we are forced into with this recognition is not careless, but filled with care for what had been lost - precisely because what had been lost had been dear to us. It was dear to us by virtue of the fact that it provided the ground on which we stood. Laughter, in this sense, robs us of any firm footing.

\section{Life is Elsewhere (1986) - The poetry of suspicion ${ }^{3}$}

Do we not covet the lives of those young romantic lyrical poets who die young, in an explosion of passion, after having lived life to the hilt? But surely our envy is not so easily aroused, and a life so lived cannot be enough to give birth to the tinge of resentment we feel when reading about their lives. What attracts us is not only their lives, but their linguistic revelry in creating and understanding a form of deep truth. We suspect them of understanding the truth of being. Because we harbour this suspicion, we find it possible to understand arguments such as those Gadamer uses to make us believe that art reveals the truth of reality.

It should be obvious that this address is not directed to those who do not suspect poetry in this way. For them Kundera's musings on being and poetry could only be a story which they have read and by which they have remained untouched. This novel can never 'work' for them. If Kundera's novel 'works' at all, it does so because the reader believes in poetry; suspects it of containing some sort of truth.

Is there not something mystical and deep about poetry's relation to our inner existence? It is indeed the raw, concise expression of being.

In the novel, Life is Elsewhere, Jaromil comes to believe that he is one of the elect, that Truth has chosen his pen as her lyre and that he understands truth, because he is sensitive to her beguiling voice. We are forced to laugh at his presumptions, which become ridiculous in the face of his inexperience. We have to laugh at the sham that is his poetry, the lie he calls his inner being. Together with Kundera (for he leads us into this trap as we read on) we ironise the young poet's inability to become part of the real world. Our laughter is filled with derision. We come to believe that Jaromil lives in the mirrored house of poetry and that his truth is removed

In this section I am much indebted to the insights of Francois Ricard (1991). 
from true being. We come to understand him as an ersatz poet who will never reach the truth in the way Rimbaud did.

The reader, however, slowly comes to understand that Jaromil is, indeed, gifted and that his poetry is not of the worst kind. The reader is forced into a corner from which he must rethink and question his own evaluation of poetry. Exactly what is it that makes good poetry good? Perhaps the reader, in his laughter, had up to this point suspected that he was one of the elect, one who could fathom true being, by understanding good poetry. His laughter is slowly infiltrated by doubt. Kundera (1986:271) has set a trap for "snaring Rimbaud, Lermontov, lyricism and youth". At first it was possible to play off our hero, Rimbaud, against his false antithesis, Jaromil. Now we understand that those two poets are one and that Kundera flogs the one as he does the other. By virtue of what judgement were we laughing at an earlier stage in the novel? At that point Rimbaud was still authentic, our own inner experience was still authentic, but now we seem to sense the void Kundera has led us into and as we look around us, we perceive nothing but our own hollow laugh, fading and then turning against ourselves.

Are we touched by Jaromil's life? Undoubtedly. He is at once comic and monstrous. We cannot ignore this latter part of him. In the beginning he was ineffectual in the realm of reality, as he was in poetry, but now he has sentenced a man to death and a woman to imprisonment. We can no longer laugh derisively; the moment has come to judge. We cannot but condemn him and his poetry. Jaromil, Lermontov, Pushkin, Rimbaud, all poetry becomes monstrous as Kundera leads us through their biographies. Poetry stands unmasked and if it forms a part of our being, it is a dark part - not truthful, but deceitful.

How do we finally understand this unmasking? Kundera's novel is written in a poetic style. He has not drawn us into the world of poetry by using ordinary language, he drew us into poetry by using poetry. Our suspicion of poetry has come full circle. The search for truth has ended in deceit. All that remains is Kundera's laughter, but he cannot be laughing at us, after all, he is the poet. That hollow laugh must be directed at himself.

Characters, readers, author - all have been demolished by irony. The book implodes into nothingness and so does being, which is its subject. 
In this novel, the 'dialectics of irony' is once again at work, but this time, playing its game on an even more intimate level with the reader and the author. This book 'works' because of the readers' assumptions about poetry and truth. The reader keeps looking for this truth and in so doing, sides with the authorial voice in condemning Jaromil. The reader, however, is betrayed by the author - he makes laughable that which we had believed. But just as soon as we reconfigure and set ourselves in action against the ironising betrayal of the author, the text itself betrays the author and silences his laughter, so that the reader finds himself incapable of defending his position against anyone. The text itself is finally betrayed by poetry, which has in turn been ironised by the author. In this circle of betrayal, the reader finds himself in the void of laughter which takes the place of his seriousness.

\section{Being, laughter, and forgetting}

How can we examine being through the oddly juxtaposed couple of laughter and forgetting? What connects them to being and to each other?

With the act of laughter, as with the act of forgetting, the crossing of a boundary, a border occurs. Crossing the line that divides remembering and forgetting, seriousness and laughter, constitutes an entering into the world of meaninglessness and death. To no longer remember ourselves is to transgress the borders of being. Without the thick innards which is memory, the body becomes an empty shell and a mere perpetual movement without direction and reason.

The struggle for control over the future, says Kundera, is merely a struggle for attaining power over the past. Once one has power over the past, one can command the meaning or non-meaning of the future. The cut-andpaste action of memory shapes the past. If that memory is faulty, it makes mistakes, and these mistakes have the characteristics of irony which gives rise to laughter. With the act of forgetting, laughter gets to govern the meaning of the present.

Kundera discusses two kinds of laughter - each indicating an opposing metaphysical presupposition. The laughter of angels describes the kind of laughter that embodies happiness and optimism. This is the laughter of lyricism which leads the laughing being to believe in the truth of well- 
being. This is (also) the fanatic laughter of totalitarianism, of religion, and of true faith in the future. This laughter is in cahoots with forgetting; it edits the past so as to fit in with its presuppositions.

Opposing this mode of laughter, we find the devilish laughter of nothingness. This is the laughter of memory, the memory of senseless repetition. This laughter is propped up by the metaphysics of nothingness. To believe in something is to be serious. Devilish laughter undercuts all seriousness. This laughter demolishes the seriousness of sexual intercourse and funerals - it does so by appropriating the mechanisms of irony. This is the laughter that says: 'We are engaged in this (or that) action, but we understand that what we do, is nothing.' In short, it is the laughter of absurdity.

Real humour constitutes the harmony of being and nothingness and thus it lies somewhere between these two extremes. Kundera tells us that the wisdom of the novel does not lie in proposing answers, but rather in juxtaposing questions. (In this case he means to juxtapose the two forms of laughter without either of them dominating the other.)

But we have to ask whether Kundera is not lying. Is the reader equally effected by the two forms of laughter - metaphysical totalitarianism and metaphysical nihilism?

The Book of Laughter and Forgetting (1980) ends with the melancholy of this last transgression. A meeting of the meaningful with the meaningless and the laughter of nothingness closes the scene. A certain fear lies in the recognition of nothingness, a certain impotence and negation. Kundera, remembering his prescripts for the novel, could not throw his whole weight behind this laughter. But is this laughter not endlessly preferable to the laughter of all-ness, the all-encompassing laughter of angels which commands one to join them - and in failing to do so, we are demolished? This is the strength of Kundera's political analyses. They do not only condemn totalitarian politics, but also totalitarian metaphysics, wherever it rears its head. Kundera constantly evokes the laughter of angels, but when he joins in the laughter, he is no doubt laughing the laughter of the devil.

What then of the laughter of true being, the laughter that governs the middle ground that does not degenerate into either of the extremes? Does it not remain a possibility? I think not, for those who understand humour, know that humour always undercuts what is serious, what is endowed with 
meaning. In the intoxication of laughter, there remains no place for meaning and humour slides helplessly, irrevocably into the excess of the devil's laughter.

This seems to be the function of the 'dialectics of irony': It creates the possibility of seriousness only to subvert it again. Let us for a moment be serious about the laughter of angels. It is not the laughter of loss, but the laughter of certainty, the same laughter that constitutes truth. This truth is ultimately serious. The laughter of angels is simply seriousness existing incognito. Kundera, once again, sets up the possibility for 'something' to exist. Perhaps, he says, there is a position midway between something and nothing. But the laughter of the devil undercuts this possibility. All the possibilities we are offered end up being ironised and so destroyed.

We laugh with Kundera, for his laughter is catching. But before long, we find that his humour has led us to the opening of the void. The void opens there where we laugh in excess of ourselves, where we forget ourselves, where what remains, is not being, but purely laughter. We describe the laughter of irony by saying that it is light, it defies heaviness, it resists being drawn into heaviness.

\section{Being and lightness}

What characterizes being? Being, we are told, is above all characterized by lightness. This 'lightness' has two possible binary opposites. The first and most obvious of these, is heaviness. To this meaning, we shall return shortly. The title of the book, The Unbearable Lightness of Being (1984), leads us away from the opposite of lightness which is darkness. Nonetheless it is in the reflection of light that Tereza sees her body, the same light in which Tomas sees the dissimilarities of his lovers's movements and bodies. This light illuminates action. Thus, through this crack in the meaning of lightness, in this disparity of opposites, we see that being is also action. The novelist has to show us the actions of his characters in order to show us the meaning of being. Their acts become the backdrop, the active scene from which the themes of the novel emanate.

Of course the themes of this novel revolve around the primary meaning of lightness, a concept which stands in opposition to the word heaviness. This lightness, as we have just seen at the end of the previous section, is 
found in laughter and irony. It is the laughter that resounds over the absence of meaning. But lightness, in the sense of laughter, is not an action that establishes itself. It is a re-action. It is an act performed in reaction to whatever is experienced. From the start, the lightness of being is not an assertion, it is an open possibility - the possibility that finds its existence in a choice. The lightness of being is thus not a pre-meditated answer to the question 'What is being?', but a problem stated in the form of a possibility that becomes possible only by the active choice of a human being.

Once again we hear Kundera saying that the novel does not provide answers, but merely different possibilities. ${ }^{4}$ So far we seem to have come to the conclusion that Kundera favours some possibilities over others. The outcome of the argument is, however of no crucial importance - the argument provides us with a way of reading, nothing more. It is the path we have chosen, and it should be obvious that if it were today a windy and cloudy day, we might have chosen another. Thus the specific path is not all-important. What is important, is that we walk it. This assures the reader and the writer that we are making progress, which is naturally a lie, because we understand that we are performing an action (in this case we are walking down a specific path), not in order to reach a destination, but merely for the sake of the movement, which confers meaning on our reading.

Being is light because it is devoid of repetition. Only through repetition can our acts become solid. We live our lives but once and therefore it becomes light and meaningless. This is the lightness of irony, for we understand that we are performing in a rehearsal for which there will be no opening night. We are confronted with the idiom Einmal ist keinmal.

Nietzsche makes his demon ask us the heaviest question of all (see Nietzsche, 1965). The question wants to know how we would react to life if it were infinitely heavy, if we lived our lives again and again, each life the perfect mirror of the previous one. Nietzsche indicates that a life filled to the brim with heaviness, becomes the most impossible of all tasks.

4 For an exposition of Kundera's own understanding on this form of contingency, see The Art of the Novel (1988). 
Kundera deftly inverts the question. It now reads as follows: 'How would you react if your life were only to be the faint outline of a sketch that will never be completed - a figure that will never be solid enough to cast a shadow?' Kundera sets out to show us, through the actions of his characters, the possible answers that might come to us as we live our lives. I say again that Kundera 'presents' us with these possibilities, but that these possibilities do not exist without active choice - decisive actions.

Tereza and Tomas meet each other as the result of a multitude of chance circumstances. There is nothing heavy about their meeting. It results from a superior's illness, Beethoven, an open book, and a glass of cognac. How is it possible that this chance encounter eventually results in Beethoven's heavy refrain "Ess muss sein. Ess muss sein"? Having read the pages of the last novel, the reader cocks his head and strains his ear for the echo of a dying god, for the laughter that is about to erupt from the lightness (the Einmal ist keinmal) of being. It is still natural for us to draw a straight upward-slanting line through the separate works of an author. We wait for the reworking of an old theme. Here, in this novel, the theme is undoubtedly still audible, in fact, it is the first thing we hear when we pick up the book. Yet, suddenly the unmistakable Ess muss sein establishes a counterpoint to the lightness and we cannot ignore it for another moment.

To trace the origins of this Ess muss sein, we may choose to follow the actions of any one of the main characters of the novel (Tomas, Sabina, Franz, Tereza). I shall follow Tomas. His Ess muss sein, his heaviness, is the will to be a doctor, specifically, a surgeon. It has always been his destiny. But the word destiny rings false. This heaviness has very little to do with a cosmic plan and everything to do with individual choice. Tomas follows his Ess muss sein to Switzerland and there he lives his life as he must. But our actions are more complicated than this and Kundera indicates that our choices, even though they be the outcome of contingency and lightness, may lose this characteristic lightness. The lightness that was once his chance encounter with Tereza, has become heavy. It has gained weight by his choice and by his love for her. When she returns to Prague, her heaviness drags him down and he follows her. In Prague he is faced with the dichotomy between the Ess muss sein of his profession on the one hand and on the other, the lightness which he bestows on politics. $\mathrm{He}$ is forced to retract the negative statements against the party in order to 
keep on working as a surgeon - to follow his initial Ess muss sein. His refusal to do so seems to indicate a choice for lightness - against his profession and against the heaviness of totalitarian politics.

But we know already that this decision does not lead him away from heaviness, it leads him to Tereza, his other Ess muss sein. His choice against politics places him, for a moment in limbo between lightness and heaviness. His life without his profession is light, his life with Tereza, heavy.

Why this affirmation of heaviness in the one case and not in the other? The answer is not as obvious as it seems. It is not the choice of a woman above a profession, which seems to be the only natural human choice. This choice becomes a writer's problem. Kundera is trying to solve the problem of being and weight.

In the previous novels we have seen him choosing for lightness, laughter and nothingness. Here Kundera seems to leave us with true ambiguity instead of an answer.

Tomas does not die in the realm of the idyll. He does not enter true happiness (the mode of being of kitsch). He dies in the heaviness of his choice. The lightness that defines his meeting with Tereza has become heavy. But does this reverberating sound of his Ess muss sein constitute an end to the lightness, something that fills the void that was occupied by the heaviness of god? I think not. His ultimate choice comes from the lightness of individual choice. The subject of his choice becomes heavy only when he accepts the choice as his own. But the very possibility of choice makes the choice light.

This novel verges on the ambiguous. We find no clear choice between lightness and heaviness at the end of the story. Kundera merely presents us with possibilities. In his latest novel, Immortality (1991), I see a reversion to the choice for absolute lightness. The Unbearable Lightness of Being seems to constitute the only breather in this author's works. This is the only novel in which the devilish laughter that leads to nothingness is not constantly audible. 


\section{Being and death}

Let us read Immortality (1991) by unravelling the following statement: Being has the weight of an image, a gesture.

All characters, says Kundera, contains a basis, a reason, a Grund which is the cause of its actions. Without grasping this basis, one cannot understand the person, or what motivates him to act. This Grund, he is further convinced, "has the nature of a metaphor" (Kundera, 1991:265).

We are concerned with the question, 'What is being?' or 'What is called being?'; this is the question we are asking Kundera to answer.

From the beginning we are made to understand that being too has its Grund in a metaphor, the metaphor of an image or a gesture. To understand what being is, it follows that we have to understand the meaning or value of an image or gesture.

As we have seen in the previous section, the meaning of being is determined by its weight. If it is true that the basis of being resides in an image or a gesture, we have to determine the possible weight of that image in order to be able to attach a value to it.

For these reasons we start with the statement: Being has the weight of an image or a gesture. By defining the meaning of this statement, we are attempting to answer the question: 'What is being?'

Following the dictates of the text to a certain degree, we shall not attempt to homogenize the thematic nuances under which Kundera scrutinizes being, but rather attempt to find being, as the author presents it, in different places and in different circumstances.

In The Unbearable Lightness of Being we have traced a rather ambiguous answer to much the same question. Perhaps Kundera is ready to rid his novel of that ambiguity now, because it is, after all, difficult to perceive a moment of ambiguity when one is faced with the heaviness of undeniable mortality.

Shortly before her death, Agnes uses this image to outline being: "Being: becoming a fountain, a fountain on which the universe falls like a warm rain" (Kundera, 1991:288). This image traces, what Bataille (1988:xi) calls "the desire to be everything, to identify with the entirety of the 
universe". It is an image which outlines a desire for expansion, a wish to embrace the all. Simultaneously this desire to encompass space is also a wish to embrace all time. For being to become the all-encompassing, it has to embrace time in its entirety. In this image, we meet face-to-face, the desire for immortality. This image (which becomes breathtaking and climactic by dint of its sheer magnitude) is shattered by a seemingly small chance occurrence. Agnes and her desire are both erased by the figure of a girl sitting in the middle of the road. The only response we can show to the dichotomy that exists between her desire and the transitoriness of the image she assigns to being, is melancholy.

Perhaps, then, mortality undercuts the heaviness of being and turns it into something light and ephemeral. But being in its essence remains to be examined; being devoid of its inevitable telos (which makes it light). If we catch the image of being before it vanishes, it might turn out to possess some weight after all.

But, in turning our back on death, we inevitably face birth. Agnes, we learn, is born out of an image, a gesture. She is, however, unable to fill that image with herself and so, unable to make it heavy. This inability follows from the fact that the gesture from which she is born, is not unique to her. Kundera observes a woman performing a gesture with her hand when she greets someone. That image, that gesture is the basis from which Agnes is born. In no way does Agnes's defining feature, the gesture, become her own, it may be used by anyone. Kundera (1991:8) aphorizes the problem: "Many people, few gestures" (8). Agnes dies, but her gesture carries on. At the end of the novel her sister has fully appropriated her gesture and the gesture, which once signified Agnes's Grund, becomes only a parody of what she once was. The image of that gesture becomes weightless in its transposability. It always reveals the same meaning and yet in this case, designates another, opposing being.

We take our gestures and our faces, for that matter, to represent our core selves. That is after all what helps us get over the initial jolt of having been thrown into this world. Now this comforting assumption has to be questioned. As Agnes browses through a magazine, she comes to understand that the freedom of photography has lead to the demise of identity and of difference. Agnes understands that the face, with its features 
reproduced in a million other faces cannot contain traces of the self - the self, to be just that, has to be heavier than the reproduced images of modern photography. It is clear that being can be constituted from otherness. Thus Agnes attempts to escape sameness. To become oneself and only that, one must be capable of becoming other. But Agnes keeps seeing herself in others, and is, finally, incapable of being herself. The irony of seeing those traits we have adopted for ourselves constantly being repeated in others, diminishes our own otherness and makes the boundaries of being seem fuzzy and uncontainable.

What remains of us after death? A gesture, a certain image. If you are an ordinary person, one who has not written books or acted in films, your gesture is bound to evaporate very quickly. Celebrities have their gestures examined, twisted into lies, spat upon, belittled, changed. Bettina lies about the image of Goethe. Hemingway's biographer does the same for his image. Their images are as light as paper and can be cut and pasted as easily.

Surely a glimpse of the truth of being must be caught in the image of love. This is our one true emotion. But before love can provide answers to our questions on being, it is forced to answer the question asked by Nietzsche's demon. The demon wants to know from the loving couple whether they would like to spend their lives together in the next life; and the next? Or would you prefer never to see each other again? Agnes chooses never to see Paul again. The stability of love is an illusion - the image of romantic lovers, for ever madly and inseparably intertwined in embrace starts burning as soon as it is confronted with its truth. The image is unmasked as feeble when it is not strong enough to sustain the 'Yes! Was that love? Then once more'. In its eternal perhaps, love becomes featherlight.

So, the self, the core of being, has made room for the image. There is no self, but the hundreds of selves constituted by our images in other people's eyes. Agnes does not leave Rubens, her lover, because of something that has happened to her self. She sees her own physical image tainted and imagines him seeing her like that. Her self transposes the image it has of itself to the image that it may form in Rubens's mind. An intricate transposition, no doubt, as much as it is a fictional transposition, but it is 
enough to end their erotic love story in an air of misunderstood melancholy. A radical perspectivism underlies this episode. What governs this episode, is not a story, or even a multi-dimensional proliferation of stories which we can at least attempt to piece together. A hundred narratives colliding would make Agnes's decision heavy and loaded with meaning. What governs this episode is rather the instantaneous flash of the camera, a flash which takes over the entire self for that instant. The image that develops from that instant is light and almost without Grund.

Being, governed by the flash of the camera, also has a specific social face. Being-in-the-world has given way to being-among-images. The truth of our being is in the hands of what Kundera calls the Imagologues. Advertising, opinion polls, talk-radio, the news - all these facets of our daily lives become the creators of the images in which we find ourselves, from which we may choose the meaning of our lives. From these images, we are forced to deduce our social being, for we have little else to go on. When we hear that violence in the city has shown a remarkable decline in the past forty eight hours, we are bound to uncork a bottle in celebration, while next door, one's neighbour is being strangled by a mad rapist.

The images created for us by advertising have lost all the heaviness of tragedy. We know Beethoven's Ninth not from the concert hall, but from the perfume advertisement. The images we are confronted with is no longer greater than human life, they are scaled down for consumption. For this reason alone, the heaviness of tragedy is absent from our lives. In the world of the imagologue, being can hardly be a serious matter.

But we cannot stand the fleetingness of these images. We rebel against their gratuitousness, their ephemerality, their contingency. These images, which are meant to provide the Grund of our being, are themselves weighed and found wanting. This is the gesture meant to deny contingency, the gesture of longing for immortality: "she tilted her head slightly, covered her face with a vague, rather melancholy smile, placed her fingertips between her breasts and ... threw her hands forward" (Kundera, 1991:183). This is the image of the human self wanting to transcend itself, its own transparent image. The image of the hands being thrown forward, contains the desire for true, heavy being. It is the desire to see being projected into the future. Being is more than being thrown into the world, 
it is more than being-in-the-world. It is the desire to become being-in-thefuture. Kundera, however, leaves us with the knowledge that we cannot project being into the future. The best we can do is to project an image of that being into the future. But it should be remembered that we have no control over that image, for as we have seen, it is infinitely light and subject to chance and distortion. After all, Kundera (1991:240) even makes Goethe and Hemingway say "things [they] would probably never say on [their] own".

We are left with a final metaphor. Avenarius rebels against the lightness of the images that people consider heavy enough to describe being. His whole life, his whole being takes part in this revolt. He becomes, to the reader, a figure of hope. But when Kundera eventually thinks up a metaphor that defines Avenarius, we are met with another metaphor which derives its absolute lightness from powerlessness and joylessness. Kundera (1991:387) describes him by saying: "You play with the world like a melancholy child who has no little brother". It becomes apparent that there is no escape from lightness, and once again this lightness becomes, for us, heavy like death.

\section{In conclusion}

Both Nietzsche and Kundera's questions seem to have become one, namely 'What would you do if your life were infinitely light/heavy?' The pure mirror image of repetition becomes light and meaningless. It demands something to weigh it down. In both the images of lightness and heaviness the threat of meaninglessness exists.

In Unbearable Lightness of Being Kundera seems to indicate that individual choice provides a moment of heaviness. But in Immortality he questions the existence of a notion such as true individualism. So far, Kundera's oeuvre leaves us with very little doubt that the 'dialectics of irony' is what governs being. Nothing exists which will not ultimately be consumed by ironising lightness. If Nietzsche proclaims the death of God, then Kundera proclaims the reign of irony.

Why is Kundera so convincing about the all-pervasiveness of irony? Of course philosophy can be convincing through the medium of argumentation. But when one considers the present subject, namely being, it 
becomes clear that it is not a subject easily argued. Both Nietzsche and Sartre (but also Heidegger) found it easier to cope with the subject matter at hand in a more or less literary fashion.

We may be convinced by a philosophical argument that has the possibility of being true. But when the reader picks up a Kundera novel, he is not only confronted by what might possibly be true, but, more importantly, by characters that might be his own true possibilities. The reader identifies with the characters and so, becomes, part of the question he is attempting to find an answer to. The more or less stable character that the reader assumes before reading the novel, is slowly subverted and turned against itself, so that the end of the novel also entails an end to the reader. Can the reader still truly love or hate without laughing at the very act? - without losing the meaning of the act, even as it is in progress?

It is clear that the void that is being described in terms of irony is the representation of what we are confronted with in postmodernity. Postmodernism takes the death of God seriously and accepts the uncertainty with which it is confronted. What should be our response towards this overpowering irony? Kundera ends his last novel by responding with a sense of melancholy. Perhaps this is the clue that must govern our responses. Previously we could respond to our world by adopting the emotion of nostalgia, an emotion that is constantly lamenting a great loss without fully accepting that loss. That was the answer of modernity. Now that we can more fully comprehend our inability to recover certainty, we are left, in the aftermath, with melancholy which does not permit us to look back, but only to forge on. Melancholy, and not nostalgia, is what will finally enable us to reconcile our existence with the absence of God.

\section{Coda: Irony as response to the tyranny of truth}

There exist two basic possible responses to the death of God. The first is to shudder, step back from the abyss, and hang onto some kind of truth in order not to lose oneself. The other is to embrace the abyss and treat all attempts to discover truth with a due amount of irony. The latter seems to be the choice of what we refer to as postmodem literature.

What does it mean to adopt this last option? Kundera's last novel, Immortality, is a good example of this choice. This novel mocks form, 
turning more in the direction of anti-form. The reader is introduced to characters that remain marginal and totally unimportant to the plot; she is introduced to philosophical ideas that are not traditionally part of the novel; the author is overtly introduced into the plot and seemingly has as little control over the novel as have the characters. These elements introduce into the novel a feeling of playfulness. There is no longer a sense in which the narrator guides the thoughts of the reader. For that, there has to be an element of design. Although it is apparent that the author creates the characters, these characters are not created by careful design. They come to life in the author's mind as he is listening to the radio, or sees an arbitrary movement of the body. Their creation as well as the actions they take part in are governed by pure chance.

With this set of givens established, the only plausible position that the reader can assume, is an ironic one. Now that we have ascertained that both the author and the reader find themselves adhering to an ironic stance, it is perhaps appropriate to attempt an appraisal of this stance.

First of all it is apparent that the ironic stance is a dangerous one. One stands a chance of losing all established values, moral and aesthetic. Why precisely should this be risked? A first tentative answer would be that it is a more interesting way of going about living, than just sticking to values which have already been established. At first this answer seems slightly weak and dangerously gung-ho, but, when carefully considered, it seems to deviate very little from the spirit of the old modernist battle-cry coined by Rimbaud: 'It is necessary to be absolutely modern'. In this sense postmodernism seems to be a radicalisation of modernism, and there is nothing within modernism, with its spirit of exploration, which seems to forbid such a radicalisation.

But this answer does not bring us far. Kundera's irony, as we have seen, goes a step further than that of Joyce or Woolf. Both aesthetic form and the writer's authority are undermined by irony. Kundera's postmodernism starts opposing the last vestiges of truth that modernism never dared part with. The modernist writer is still an authority and in modernist writing aesthetic form still dictates the boundaries of meaning. The irony of modernism is not prepared to ironise and laugh at itself. This constitutes a form of textual totalitarianism in which the reader may laugh at what the 
author says, but never laugh at the author. The author is still the knowing subject who projects a truth which one dares not ridicule or challenge when one is reading. In this respect the creation of fiction turns into a political matter. Writing, as Derrida asserts, becomes a political act. ${ }^{5}$ The author can no longer feign to know anything. All s/he is equipped with, is ideas. Whenever these ideas become truths, as opposed to mere possibilities, they become tyrannical and totalitarian.

In many ways my reading of Kundera is not highly plausible. As far as the character of the subject and specifically the subject as creator are concerned, Kundera is probably much more of a modernist than I have attempted to show. This is, however not of great importance. What is important, is that his texts open themselves to various diverse interpretations - in fact, they seem to revel in the vulnerability of their own truths. It is precisely these truths that have to be debated and discussed.

Perhaps it is true that we are risking a concept of morality in adopting this new freedom. But then it is also clear that this freedom will put an end to the monopolisation of truth. The meta-morality of freedom is not unproblematic, but it promises to test the boundaries of established moralities and is bound to engender much moral discussion about its own parameters.

\section{Bibliography}

Bataille, G. 1988. The Inner Experience. New York : State University of New York Press.

Derrida, J. 1976. Of Grammatology. Baltimore : Johns Hopkins University Press.

Heidegger, M. 1962. Being and Time. Oxford: Blackwell.

Kundera, M. 1980. The Book of Laughter and Forgetting. Harmondsworth : Penguin Books.

Kundera, M. 1982. The Joke. Harmondsworth : Penguin Books.

Kundera, M. 1984. The Unbearable Lightness of Being. London : Faber and Faber.

Kundera, M. 1986. Llfe is Elsewhere. Boston : Faber and Faber.

Kundera, M. 1988. The Art of the Novel. London : Faber and Faber.

Kundera, M. 1991. Immortality. London : Faber and Faber.

5 See Derrida (1976) - especially "Writing and Man's Exploitation by Man". 
Nietzsche, F. 1965. Die fröhliche Wissenschaft. Stuttgart : Kröner.

Ricard, F. 1991. Satan's Point of View: Towards a Reading of 'Life is Elsewhere'. In: Matuz, C. (ed.) Contemporary Literary Criticism. Detroit : Gale Research Inc. p. 239-241.

Szondi, P. 1985. Friedrich Schlegel und die romantische Ironie. In: Schauze, H. (ed.) Friedrich Schlegel und die Kunsttheorie seiner Zeit. Darmstadt : Wissenschaftliche Buchgesellschaft. 
